\title{
Exploring the Motivational Strategies Practiced by Pakistani EFL Teachers to Motivate Students in Learning English Language
}

\author{
Sehrish Khan Kakar ${ }^{1} \&$ Zahid Hussain Pathan ${ }^{1}$ \\ ${ }^{1}$ Institute of English Language \& Literature, University of Balochistan, Quetta, Pakistan \\ Correspondence: Zahid Hussain Pathan, Assistant Professor, Institute of English Language \& Literature, \\ University of Balochistan, Quetta, Pakistan. Tel: 92-333-267-1662. E-mail: pathanzahid82@yahoo.com
}

Received: November 18, 2016

Accepted: December 6, 2016 Online Published: January 19, 2017

doi:10.5539/ijel.v7n2p117

URL: http://dx.doi.org/10.5539/ijel.v7n2p117

\begin{abstract}
The purpose of this study was to investigate motivational strategies which EFL teachers employ to motivate students in learning English language and to determine the significant difference if any across male and female teachers in practicing motivational strategies in an EFL classroom. A quantitative research design was employed. An adopted questionnaire by Cheng \& Dornyei (2007) comprising of 48 close-ended items ranging from "Hardly ever" to "very often" was administered among 96 male and female EFL teachers who were teaching in government secondary schools in Quetta, Balochistan, Pakistan. To answer the two research questions of the study, both descriptive and inferential statistics were performed in SPSS (version, 21). The findings of the first research questions revealed that to promote learners' autonomy emerged as the most influential source of motivational strategy practiced by EFL teachers followed by Familiarization learners with L2-related values as the second most practiced motivational strategy. The findings of second research question revealed no statistical significant difference between male and female EFL teachers in terms of practicing motivational strategies. The findings of the present study have implications on effective English language teaching and enhancing teachers' experience and knowledge in order to motivate EFL learners by using different motivational strategies in learning English in context of Pakistan.
\end{abstract}

Keywords: motivational strategies, second or foreign language teaching, EFL teachers

\section{Introduction}

English enjoys its glory as an official language of Pakistan and is widely used as the medium of instructions in educational institutes. Pakistani EFL learners fail to acquire proficiency in the target language despite of putting endless efforts. The past studies have attributed Pakistani EFL learners' failure to an acute demotivation (Krishnan \& Pathan, 2013). To cope with this problem, EFL teachers need to keep students motivated for an effective learning. Motivation as an important key factor for learning foreign languages has been widely investigated (see Crookes \& Schmidt, 1991; Clement, Dornyei, \& Neols, 1994; Chen, Warden, \& Chang, 2005).

Teacher is considered one of the key sources to keep students motivated for learning the target language. Therefore, the strategies that English language teachers employ in enhancing the motivation of learners in learning second or foreign language effectively have been researched (e.g., Dornyei \& Csizer, 1998; Guilloteaux, 2013). This kind of research studies associates the motivational theories to practice motivational strategies which EFL teachers could utilized in EFL classroom.

The prime purpose of this study is to explore the motivational strategies employed by Pakistani EFL teacher to keep EFL learners motivated in learning English language. Motivational strategies are techniques that encourage the individuals and their behaviors; and these behaviors can be promoted by a number of different ways (Dorneyi, 2001). The past research studies have confirmed that teachers who practice motivational strategies in L2 learning process can easily Influence the L2 learner's motivation. The study by Moskovsky et al. (2013) conducted a study to examine the effects of motivational strategies employed by EFL teachers to stimulate the motivation of learners in context of Saudi Arabia by following framework of Dornyei (1994). The findings of this study portrayed that teacher practiced motivational strategies which highly influenced the motivation of L2 learners.

\section{Importance of the Research}

Dornyei \& Csizer (1998) conducted a study to identify the EFL teachers' perceptions about the motivational 
strategies and to identify that how frequently they used them in their classrooms for the motivation of students. The data was collected from 200 Hungarian teachers. This empirical study showed that teachers should be aware of motivational strategies which they could use in their practices and motivate students in classroom settings.

Al-Mahrooqi, Abrar-ul-hassan, \& Asante (2012) conducted a research in Oman. The main purpose of the study was to analyze motivational strategies used by teachers in different schools, colleges and universities. Moreover, they analyzed that how frequently EFL teachers used particular motivational strategies to motivate their students in learning English language. They found that EFL teachers used all the 48 motivational strategies as suggested by Cheng \& Dornyei (2007) and they were in favor of the strategy which was linked with the performances of the teachers in the classroom.

Moskovsky, Alrabai, Paolini, \& Ratcheva (2013) conducted a study using quasi-experimental design to examine the effects of motivational strategies used by teachers to motivate students in Saudi in EFL context. The result showed that teacher used motivational strategies which highly influenced the motivations of learners.

Solak \& Bayar (2014) conducted a research to determine the influence of factors on motivational strategies which were used by the non-English teachers at school in Turkey. They found that those teachers who were teaching English used the motivational strategies at high range.

You Ziyuan (2004) conducted a study to investigate the effect of teaching motivational strategies on students' achievement. The total 130 second year non-English major students and some teachers teaching English were selected from Jilin University. Both close-ended student questionnaire and teacher interviews were employed to collect the data. The findings revealed that in a friendly environment, the level of self-confidence of students would be increased which would pave a way for them able to achieve their ultimate ends. The researcher also determined that there was a positive relationship between the motivational strategies and the achievements of the students.

Guilloteaux \& Dornyei (2008) conducted a quantitative research using correlation design to find the relationship between teacher motivational strategies and their effects on students' motivation. The total 20 junior schools were surveyed across South Korea. The investigation was carried out among 27 teachers and 1381 learners from 40 different ESOL classrooms. Data was collected using three different instruments including student questionnaire, a post lesson teacher evaluation scale and MOLT (the motivation orientation of language teaching) classroom observation scheme. The MOLT scheme was administrated comprising from two frameworks, firstly "System of Motivational Teaching" by Dornyei (2001) and secondly "Classroom Observation Scheme (COLT)" by Spada \& Frohlich (1995). The data was analyzed using SPSS. The findings revealed a positive correlation between the teachers' use of motivational strategies and motivation of students.

Al-Mahrooqi, Abrar-ul-hassan, \& Asante (2012) conducted a research in Oman. The main purpose of the study was to analyzed motivational strategies used by teachers in different schools, colleges and universities. Moreover, they analyzed that how frequently EFL teachers used particular motivational strategies to motivate their students in learning English language. For this study, 286 teachers were selected randomly. The modified form of questionnaire was administrated. The teachers were asked to rate the 48 motivational strategies included in the questionnaire. The collected data was analyzed using descriptive statistics. They found that EFL teachers used all the 48 motivational strategies to keep students motivated for learning English language.

\section{Research Objectives}

- To determine motivational strategies employed by EFL teachers to motivate secondary high school students of Quetta in learning English language.

- To determine if there is any statistical significant difference in use of motivational strategies by male and female EFL teachers to motivate secondary high school students of Quetta in learning English language.

\section{Research Design}

Quantitative research design was employed in the present study. Dornyei \& Ushioda (2013) stated that quantitative method is systematic, rigorous, tightly controlled, involving precise measurement and producing reliable and replicable data that are generalisable to other context.

\subsection{Research Sample}

The sample comprised 96 EFL teachers (48 male teachers and 48 female teachers) from different thirteen government secondary schools located in Quetta, Balochistan, Pakistan. The following table shows the demography of the study. All the teachers were teaching English for five years on an average. 


\subsection{Research Instrument}

The questionnaire consisting of 48 items based on 10 motivational strategies was adopted from the study by Cheng \& Dörnyei (2007). The following table reveals the distribution of the items of the questionnaire against each construct:

Table 1. Distribution of items in the questionnaire

\begin{tabular}{ll}
\hline Motivational Constructs & Items in the Questionnaire \\
\hline Proper teacher behavior & $02,17,23,40,47$ \\
Recognize students' effort & $08,15,42,46$ \\
Promote learners' self-confidence & $34,36,28,11,33$ \\
Creating a pleasant classroom climate & $30,01,41,21$ \\
Present tasks properly & 06,25 \\
Increase learners' goal-orientedness & $20,26,10,31$ \\
Make the learning tasks stimulating & $18,12,45,43,27,13$, \\
Familiarise learners with L2-related values & $39,38,04,32,07,09,19$ \\
Promote group cohesiveness and group norms & $05,44,03,35,16$ \\
Promote learners' autonomy & $37,14,24,48,29,22$ \\
\hline
\end{tabular}

\subsection{Pilot Study}

To determine the reliability of items in the questionnaire, the pilot study was conducted with 10 male and 10 female EFL teachers from two government secondary schools in Quetta, Balochistan, Pakistan. The item reliability statistics was performed in the SPSS. The findings obtained from the "Cronbach's alpha test" was 0.91 which is considered reliable (Creswell \& Clerk, 2007).

\subsection{Data Collection Procedure}

After seeking a formal permission from the head of all the schools, the questionnaire was administered among Pakistani EFL school teachers of Quetta. They were also informed of the nature of the study and were also assured of confidentiality of their responses. They were given 60 minutes to respond to all the items of the questionnaire in the presence of the researcher.

\subsection{Data Analysis}

In order to answer the first research question of the study, descriptive statistics was performed in the SPSS (Version 21) to calculate the mean and standard deviation of the responses of the research participants. To answer the second research question of the study, Independent-Samples t-test was performed in the SPSS to determine whether or not there was any statistical significant difference in the motivational strategies employed by male and female EFL teachers to motivate secondary high school students of Quetta in learning English language. According to Pallant (2013) the difference in two groups on different construct can be measured by using Independent- Sample T-test.

\section{Findings}

\subsection{Data Analysis for First Research Question}

In order to analyze the first research question of the study, the mean score and standard deviation of each motivational strategy in the questionnaire was calculated. Their findings are presented in the following Table 2:

Table 2. Findings on the motivational strategies employed by EFL teachers

\begin{tabular}{|c|c|c|}
\hline Items & Mean & Std. Deviation \\
\hline Proper teacher behavior & 20.43 & 3.16 \\
\hline Recognize students' efforts & 14.89 & 2.64 \\
\hline Promote learners' self-confidence & 18.91 & 3.31 \\
\hline Creating a pleasant classroom climate & 14.20 & 2.44 \\
\hline Presents task properly & 7.62 & 1.67 \\
\hline Increase learners' goal-orientedness & 13.07 & 2.88 \\
\hline Making the learning tasks stimulating & 17.56 & 4.47 \\
\hline Familiarize learners with L2-related values & $20.84 * *$ & 3.61 \\
\hline Promote group cohesiveness and group norms & 17.35 & 3.47 \\
\hline Promote learners' autonomy & $65.66 *$ & 2.95 \\
\hline
\end{tabular}


The Table 2 above reveals the motivational strategies employed by Pakistani EFL secondary school teachers. Promotion of learners autonomy strategy $(M=65.6, S D=2.95)$ was highly practiced motivational strategy followed by familiarize learners with L2-related values $(M=20.8, S D=3.61)$ as the second most popular strategy practiced by EFL teachers to keep students motivated in learning English language. On the contrary, present tasks properly strategy $(\mathrm{M}=7.62, \mathrm{SD}=1.67)$ emerged as the least practiced motivational strategy. It can be concluded from the findings that EFL teachers were well aware of the motivational strategies and were also practicing them in EFL classroom to keep students enthusiastic in learning the target language.

\subsection{Data Analysis for Second Research Question}

In order to analyze the second research question of the study, the Independent Samples t-test was performed. The following Table 3 illustrates the findings:

Table 3. The result of independent samples t-test

\begin{tabular}{|c|c|c|c|c|c|c|c|}
\hline \multirow[t]{2}{*}{ Motivational Strategies } & \multicolumn{2}{|c|}{ Male Teachers } & \multicolumn{5}{|c|}{ Female Teachers } \\
\hline & Mean & SD & Mean & SD & $\mathrm{t}$ & Df & $\mathrm{P}$ \\
\hline Overall Constructs & 164.60 & 25.06 & 164.54 & 22.21 & -.608 & 94 & .545 \\
\hline
\end{tabular}

It can be seen from the above Table 3, that there was no statistically significant difference between male teachers $(M=164.60, S D=25.06)$ and Female teachers $[M=164.54, S D=22.21 ; t(94)=-.608, p=.545]$. Moreover, the magnitude of the difference in the means was very small (eta squared $=0.003$ ) (Cohen, 1988).

\section{Discussion}

Of the ten motivational strategies suggested by Cheng \& Dornyei (2007), majority of Pakistani EFL teachers reported that for enhancing the motivation of EFL learners, they employed promote learners autonomy motivational strategy. Noels, Clement, \& Pelletier (1999) also found promote learners autonomy very influential in their study in which they examined the motivational impact of communicative style of language teacher. The findings of this study showed that teachers were strongly supporting learner's autonomy and the feedback which they were providing to learners showed a positive relationship with learner's autonomy. In the same vein, Dickinson (1995) asserted that learner with high autonomy could be able to increase their level of comprehension to achieve assigned tasks by their instructors.

Five approaches identified by Benson (2013) also support the idea of learner's autonomy in Education of language. Resource-based approach deals with the independent use of learning materials by autonomous learners; technology-based approach deals with the independent interactions of learners with the technologies of education; learners-based approach deals with the development of learner skills, means to bring change in their behavior and psychology, classroom-based approach deals with the change in teachers and learners relationship within classroom; and curriculum-based approach deals with the control of learners on curriculum. The present study confirms the fact that learner autonomy is relevant to the student-centered approach where teachers facilitate students in their learning process. To increase learner's autonomy, teachers should avoid the use of traditional teaching approach or teacher-centered approach. The finding of the present study is also contrary to the studies conducted by Al-Mahrooqi, Abrar-ul-hassan, \& Asante (2012) in Oman, Cheng, \& Dornyei (2007) in Taiwan, where promote learners autonomy emerged as the least practiced strategy which showed that EFL teachers in Oman and Taiwan were following the teacher-centered approach and students in these cultures were relying on their teachers.

In addition, the findings in the above table also illustrated that the familiarize learners with L2-related values was second highest motivational strategy. Large number of EFL teachers reported that they manipulated this motivational strategy to stimulate the motivation of their EFL learners. The finding concluded that familiarizing the learners with values of L2 is much beneficial and it depicted that teachers were motivating learners on daily basis by making them aware through the importance of English that learning English language would be very affective in their future. Teachers familiarize the learners with L2-realted values which would be helpful in motivating learners positively towards their learning by making them familiar with the benefits of learning L2.

Dornyei \& Ushioda (2013) came up with three types of values related to L2: intrinsic value, which deals with the internal interests of learners in learning L2; integrative values, deals with the positive attitudes of learners towards the culture and community of L2; instrumental values, deals with the L2 outcomes like looking for job, educational opportunities. This motivational strategy promotes the instrumental values of learners. There are 
some suggested strategies which promote these values like by making learners familiar with the L2 community or by giving them reminder about the advantages of mastering L2. Using these strategies is very beneficial and enjoyable in motivating learners in L2 process. This finding is in line with the findings of the study conducted by Alrabai (2014) in context of Saudi Arabia. In this study familiarize learners with L2-related values was also reported as a second highest motivational strategy by EFL teachers who were motivating their learners in learning of English as second or foreign language.

Based on the finding in the Table 3, the statistical significant difference was determined by using Sample independent t-test in SPSS (versions 21). The findings of the present study portrayed that, there were no statistical significant difference in the use of motivational strategy by Pakistani male and female EFL teachers. Both the groups reported that they employed all motivational strategies in order to keep their students motivated in learning English language but at different scales. The finding of the present study is in line with the findings of the study by Solak \& Bayar (2014) and they found no statistical significant difference within the use of motivational strategy across gender. The same result was found in the study conducted by Rajab, Rahman, Wahab, Shaari, Yousaf, \& Baharom (2015) in Malaysia.

\section{Conclusion}

In the past, many researchers have widely researched the motivation in learning of English as a second or foreign language but "the question of how to motivate language learners has been a neglected area in L2 motivation research" (Dornyei \& Csizer, 1998). This study was an attempt to investigate the motivational strategies which EFL teachers employed to motivate learners of government secondary high schools in learning of English language in context of Pakistan. The findings of this study revealed that "promote learners autonomy" was highly employed motivational strategy by EFL teachers. They reported that they were practicing this motivational strategy to stimulate the motivation of L2 learners to make them independent. Promote learners autonomy was emerged as an influential motivational strategy in context of Pakistan. In contrast, promote learners autonomy was emerged as a least practiced motivational strategy in context of Oman (2012) and Taiwan (2007). This difference might be due to the fact that, promote learners autonomy is a student-centered approach and EFL teachers in these context were followers of teacher-centered approach. It means that students were dependent on their teachers for their learning. Another reason was that some motivational strategies vary from context to context showing different results. The finding of this study was consistent and inconsistent with the findings of the study conducted by Al-Mahrooqi, Abrar-ul-hassan, \& Asante (2012), Cheng \& Dornyei (2007), Dornyei \& Csizer (1998) and Noels, Clement, \& Pelletier (1999).

The findings of this study also stated that male and female teachers were employing the same motivational strategies in motivation of EFL learners. This finding revealed that male and female EFL teachers were familiar with all kinds of motivational strategies and they were using all of them in motivation of EFL learners. The findings also indicated that no statistical significant difference was found in the use of motivation strategies by male and female EFL teachers. This finding was also supported by the findings of the study conducted by Solak \& Bayar (2014) and Rajab, Rahman, Wahab, Shaari, Yousaf, \& Baharom (2015).

\subsection{Implications of Findings}

Motivation has been the center of attraction in last few decades. Large number of research studies has been conducted on motivation and its impact in L2. Motivation considered as an important key factor that enhances the learning of English as a second or foreign language. Similarly, motivating learners is also an important aspect in learning English as a second or foreign language and teachers' vital role in enhancing L2 learner's motivation is also under great observation. This study has provided a great understanding to EFL teachers by exploring effective motivational strategies which they could implement in motivating learners of L2. The results also sheds light on the following aspects like improving teaching practice by using motivational strategies, providing them training programs by enhancing their experience and knowledge in order to motivate learners by using different motivational strategies in learning of English in context of Pakistan. Thus, the policy makers of education should organize teacher training programs in educational setup for EFL teachers.

\section{References}

Al-Mahrooqi, R., Abrar-Ul-Hassan, S., \& Asante, C. C. (2012). Analyzing the use of motivational strategies by EFL teachers in Oman. Malaysian Journal of ELT Research, 8(1), 36.

Alrabai, F. (2014). Motivational practices in English as a foreign language classes in Saudi Arabia: Teachers beliefs and learners perceptions. Arab World English Journal, 5(1), 224-246.

Benson, P. (2013). Teaching and researching: Autonomy in language learning. New York: Routledge. 
Benson, P. (2013). Teaching and researching: Autonomy in language learning. New York: Routledge.

Chen, J. F., Warden, C. A., \& Chang, H. T. (2005). Motivators that do not motivate: The case of Chinese EFL learners and the influence of culture on motivation. Tesol Quarterly, 39(4), 609-633. https://doi.org/10.2307/3588524

Cheng, H. F., \& Dörnyei, Z. (2007). The use of motivational strategies in language instruction: The case of EFL teaching in Taiwan. International Journal of Innovation in Language Learning and Teaching, 1(1), 153-174. https://doi.org/10.2167/illt048.0

Clément, R., Dörnyei, Z., \& Noels, K. A. (1994).Motivation, self-confidence, and group cohesion in the foreign language classroom. Language Learning, 44(3), 417-448. https://doi.org/10.1111/j.1467-1770.1994.tb01113.x

Cohen, J. (1988). Statistical power analysis for the behavioural sciences. Hillside, NJ: Lawrence Earlbaum Associates.

Crookes, G., \& Schmit, R. (1991). Motivation: Reopening the research agenda. Language Learning, 41(4), 469-512.

Csizér, K., \& Dörnyei, Z. (2005). The internal structure of language learning motivation and its relationship with language choice and learning effort. The Modern Language Journal, 89(1), 19-36. https://doi.org/10.1111/j.0026-7902.2005.00263.x

Deci, E. L., \& Ryan, R. M. (1985). The general causality orientations scale: Self-determination in personality. Journal of Research in Personality, 19(2), 109-134. https://doi.org/10.1016/0092-6566(85)90023-6

Dickinson, L. (1995). Autonomy and motivation a literature review. System, 23(2), 165-174. https://doi.org/10.1016/0346-251X(95)00005-5

Dörnyei, Z. (1994). Motivation and motivating in the foreign language classroom. The Modern Language Journal, 78(3), 273-284. https://doi.org/10.1111/j.1540-4781.1994.tb02042.x

Dörnyei, Z. (1998). Motivation in second and foreign language learning. Language Teaching, 31(3), 117-135. https://doi.org/10.1017/S026144480001315X

Dörnyei, Z. (2000). Motivation in action: Towards a process-oriented conceptualisation of student motivation. British Journal of Educational Psychology, 70(4), 519-538. https://doi.org/10.1348/000709900158281

Dornyei, Z. (2001). Motivational strategies in the language classroom. Cambridge: CUP. https://doi.org/10.1017/CBO9780511667343

Dornyei, Z. (2005). The psychology of the language learner. US: Lawrence Erlbaum Associates.

Dörnyei, Z., \& Csizér, K. (1998). Ten commandments for motivating language learners: Results of an empirical study. Language Teaching Research, 2(3), 203-229. https://doi.org/10.1191/136216898668159830

Dörnyei, Z., \& Ushioda, E. (2013). Teaching and Researching: Motivation. New York: Routledge.

Ellis, R. (1997). SLA Research and Language Teaching. New York: Oxford University Press.

Gardner, R. C. (1985). Social psychology and second language learning: The role of attitudes and motivation. London: Arnold.

Guilloteaux, M. J. (2013). Motivational strategies for the language classroom: Perceptions of Korean secondary school English teachers. System, 41(1), 3-14. https://doi.org/10.1016/j.system.2012.12.002

Guilloteaux, M. J., \& Dörnyei, Z. (2008). Motivating language learners: A classroom-oriented investigation of the effects of motivational strategies on student motivation. TESOL Quarterly, 55-77. https://doi.org/10.1002/j.1545-7249.2008.tb00207.x

Krishnan, K. S. D., \& Pathan, Z. H. (2013). Investigating Demotivation in Learning English: An Extension to Sakai and Kikuchi's (2009) Framework. Advances in Language and Literary Studies, 4(2), 124-131. https://doi.org/10.7575/aiac.alls.v.4n.2p.124

Moskovsky, C., Alrabai, F., Paolini, S., \& Ratcheva, S. (2013). The effects of teachers' motivational strategies on learners' motivation: A controlled investigation of second language acquisition. Language Learning, 63(1), 34-62. https://doi.org/10.1111/j.1467-9922.2012.00717.x

Noels, K. A., Clément, R., \& Pelletier, L. G. (1999). Perceptions of teachers' communicative style and students' intrinsic and extrinsic motivation. The Modern Language Journal, 83(1), 23-34. 
https://doi.org/10.1111/0026-7902.00003

Pallant, J. (2013). SPSS survival manual. London: McGraw-Hill Education (UK).

Rajab, A., Rahman, H. A., Wahab, S. R. A., Shaari, R., Yusof, M. A. M., \& Baharom, A. H. (2015). Motivational strategies among higher learning practitioners. European Journal of Business and Social Sciences, 4(8), 154-162.

Richards, J. C. (2003). 30 Years of TEFL/TESL: A personal reflection. TEFLIN Journal-A Publication on the Teaching and Learning of English, 14(1), 14-57.

Ryan, R. M., \& Deci, E. L. (2000). Intrinsic and extrinsic motivations: Classic definitions and new directions. Contemporary Educational Psychology, 25(1), 54-67. https://doi.org/10.1006/ceps.1999.1020

Sawyer, M. (2007). Motivation to learn a foreign language: Where does it come from, where does it go? Language and Culture, 10, 33-42.

Solak, E., \& Bayar, B. (2014). The factors influencing the motivational strategy use of non-native English teachers. International Journal of Education and Research, 2, 1-12.

You, Z. (2004). The role of motivational strategies in English language learning: an investigation into the relationship between the student language achievement level at Jilin University and their motivational strategies. Teaching English in China, 3, 72-73.

\section{Copyrights}

Copyright for this article is retained by the author(s), with first publication rights granted to the journal.

This is an open-access article distributed under the terms and conditions of the Creative Commons Attribution license (http://creativecommons.org/licenses/by/4.0/). 